\title{
The Agadir Agreement: The Capability Traps of Isomorphic Mimicry
}

\author{
Christos Kourtelis (iD) \\ School of Social Sciences and Humanities, Loughborough University, Herbert Manzoni Building, Loughborough LE11 3TU, UK \\ Email: c.kourtelis@lboro.ac.uk
}

(Received 10 March 2020; revised 1 September 2020; accepted 11 October 2020; first published online 14 January 2021)

\begin{abstract}
In 2004, Morocco, Tunisia, Egypt, and Jordan signed the Agadir Agreement (AA), a free trade agreement with intention of encouraging closer cooperation in trade. The AA came into force in 2007 and relies on the EU's rules of origin. Contrary to existing explanations, which suggest that the little impact of the AA on intraregional trade is a result of the local political elites in the agreement and of weak state institutions, this article amends the concept of isomorphic mimicry to shed some light on the ineffectiveness of the AA. It claims that instead of acting as a vehicle for regional integration, the AA generated two capability traps: premature load bearing and the reproduction of the structural weaknesses of Arab Mediterranean economies. As a result, the AA does not act as an instrument of intraregional cooperation and inclusive growth.
\end{abstract}

Keywords: Agadir Agreement; isomorphic mimicry; regional integration; rules of origin; international trade

\section{Introduction}

The AA is a preferential trade agreement that was signed on 25 February 2004 between Morocco, Tunisia, Egypt, and Jordan. According to the Agadir Technical Unit (ATU), the AA aims to create a free trade area in accordance with the provisions of the General Agreement on Tariffs and Trade; to coordinate the sectoral policies of the four participant countries, especially in foreign trade, agriculture, industry, and services; and to approximate their legislation in these areas in order to foster their economic integration (Agadir Technical Unit, 2015).

The AA was welcomed by the EU as an Arab Mediterranean initiative for promoting SouthSouth cooperation. Yet, this sub-regional initiative is a part of a wider context that simultaneously fosters Arab integration and the relationship of its members with the EU. On one side, the Pan-Arab free trade area, the Greater Arab Free Trade Agreement (GAFTA) was signed in 1997 and managed to eliminate tariffs in industrial goods in 2005. On the other side, the Arab countries signed bilateral Association Agreements with the EU and since the Barcelona Process worked with the EU towards the creation of a Mediterranean Free Trade Area.

Regional trade integration between the Arab Mediterranean countries is strengthened further as the AA contains a provision allowing the four countries to cumulate origin. Cumulation is the term used to describe a system that allows products originating in country A to be further processed or added to products originating in country B, just as if they had originated in country B (European Commission, n.d.). This system comprises a set of technical criteria that determine whether a product qualifies for preferential treatment (i.e. access to a market). In the Euro-Med area, the diagonal cumulation of origin applies, meaning that rules of origin can cumulate between Arab countries, but only if they belong to a common free trade area, such

(C) The Author(s), 2021. Published by Cambridge University Press. This is an Open Access article, distributed under the terms of the Creative Commons Attribution licence (http://creativecommons.org/licenses/by/4.0/), which permits unrestricted re-use, distribution, and reproduction in any medium, provided the original work is properly cited. 
as the AA. Through this prism, the participant countries can gain increased access to the EU market and stimulate trade between them.

According to both the EU and the ATU, key to the development of regional trade and access to the EU market is that the rules of origin in the AA should follow the Pan-European rules of origin (since 2005, these rules are referred as Pan-Euro-Mediterranean rules of origin) (Agadir Technical Unit, 2015). Although the existing literature on the topic acknowledges that intraregional integration remains below potential (for a comparison between the different Middle East and North Africa (MENA) trade agreements see Freund and Portugal-Perez, 2012) and that trade relations among the four parties have not improved significantly as a result of the AA initiative (for a comprehensive view of the trade relations between the participant countries, see WTO, 2018), it claims that its ineffectiveness is an outcome of the limited interest of the participant countries in the AA and of the weak state institutions that are unprepared to implement such trade agreements (Al-Atrash and Yousef, 2000; Boussetta, 2008; Abdmoulah, 2011; Freund and Portugal-Perez, 2012; Khodeir, 2017).

This article challenges these assumptions. It argues that such narratives offer a distorted view of the AA with the following results. First, such explanations turn the spotlight on problems that are supposed to be endemic of developing countries and overlook aspects of the agreement, which are constructed (and promoted) by policymakers in developed countries (in this case in the EU). Second, they tend to highlight the role of the local elites, as self-interested agents, who care only about their own survival. In this way, they overlook structural problems of the local political economy, which inform the (in)effectiveness of the AA.

As the aim of this research is to re-evaluate the AA, the next paragraphs answer the following questions: Why do policymakers continue to support the agreement despite its problematic implementation? What are the sources of ineffectiveness of the AA?

The findings of this research suggest that the process of harmonization according to the rules and standards of the EU has become an example of isomorphic mimicry. By mimicking the EU rules of trade, local policymakers increased their legitimacy on the international stage (especially in the EU institutions). However, mimicry has created two capability traps: premature load bearing for the Arab Mediterranean states and the reinforcement of the structural weaknesses of the local economies. Instead of fostering intraregional trade between the Arab Mediterranean producers, 13 years after entering into force, the initiative has further encouraged a hub and spokes system between the EU and the four members of the AA (despite the temporary decline of trade due to the Arab revolts).

The article makes three contributions to the existing literature of regional integration of the Arab Mediterranean countries. First, it questions the dominant view of 'New Regionalism', which is premised on a myopic view of the regional political economy and trade integration. This approach neglects the structural weaknesses of the Arab Mediterranean economies and takes for granted that regulatory convergence, based on the transfer of rules that have been successful elsewhere, will lead to mutual advantages for the Arab Mediterranean states from the openness of trade (Al-Atrash and Yousef, 2000; Bowles, 2000; Nugent and Yousef, 2005; Abedini and Péridy, 2008; Khodeir, 2017).

Second, it moves beyond the literature of policy convergence for analysing the AA. Works in this area explain how differentiation mechanisms between the Arab Mediterranean countries contribute to policy convergence and attempt to identify patterns of convergence in particular policy areas or countries (Barbé and Surrallés, 2010; Wunderlich, 2010). By amending the analytical framework of isomorphic mimicry, this work sheds light on the cost of mimetic strategies to the Arab Mediterranean economies. So far in studies on regional integration the concept has been used to explain the costs of premature load bearing only on the institutional apparatus of relevant organizations and the state mechanisms of their members (Jetschke, 2009; Piccolino, 2016). In addition to the costs for the state mechanisms of the AA members, this article highlights how the governance aspect of regional integration can mask the structural weaknesses of 
regional agreements and can generate asymmetrical benefits for actors (in this case the EU) who do not appear as stakeholders of the initiative.

Third, this research fills a gap in the literature of the sub-regional integration of the Arab Mediterranean countries and the AA. So far the literature on regional integration of the Arab Mediterranean countries has focused more on the EU-Arab Mediterranean relations (and especially on the effects of the Barcelona Process) (Escribano and Jordán, 1999; Vasconcelos and Joffé, 2000; Zaafrane and Mahjoub, 2000), rather than on initiatives coming from the Arab Mediterranean partners. The few studies that attempt to explain the AA are more programmatic than analytical (Péridy, 2005; Boussetta, 2008).

Methodologically, the article uses process tracing for showing the steps of the construction of the AA as a mimetic system. As there are very few studies on the AA, the article relies on analysis of official documents that are produced by the ATU. These are collated with other primary sources and EU reports in order to evaluate the performance of the AA and the significance of its capability traps.

The article proceeds as follows. The next section reviews the literature about regional initiatives in the MENA and how the existing bibliography frames the failure of regional integration. Then the article outlines its explanatory framework: isomorphic mimicry. The analytical framework is operationalized in the last section. There the article portrays the interaction between the different stakeholders of the AA and the capability traps of isomorphic mimicry. The conclusion summarizes the findings of this research.

\section{Why Regional Trade Initiatives Fail in the MENA: A Review of the Literature}

The underdeveloped trade integration in the MENA is a well-document phenomenon. Apart from petrochemicals and natural resources, intraregional trade is at very low levels, when compared to other regions. According to the World Trade Organization, in 2015 the share of intraregional trade flows in merchandise in the MENA was the lowest in the world. It accounted for less than $10 \%$ of total merchandise exports. In the same year, the intraregional trade between countries in Africa and between the Commonwealth Independent States was about 18\% (WTO, 2015).

The position of the MENA in merchandise trade has declined further in the last four years. Developing countries generate $43 \%$ of the global merchandise trade, but the MENA participates with only $6 \%$ in world trade (WTO, 2019). Despite recording stasis or a slight decline in the last two years, the EU and the North American Free Trade Agreement continue to dominate trade among regional trade agreements. Trade within the EU represents $63 \%$ of all EU exports (WTO, 2019).

Yet, the weak performance of the MENA in the value of intraregional trade is not due to the absence of regional preferential trade agreements. On the contrary, the Arab Mediterranean countries have taken several initiatives to liberalize their trade regimes. Besides the AA, these include the Arab Maghreb Union in 1989 (between Mauritania, Morocco, Algeria, Tunisia, and Libya) and the Greater Arab free trade area, which was approved by the Economic and Social Council of the Arab League in 1997 and also includes the Arab Gulf countries. In addition to these initiatives, the Arab Mediterranean countries have concluded bilateral trade agreements with the EU and participated in regional trade initiatives beyond the MENA (for example Egypt is also a member of the Common Market for Eastern and Southern Africa). This wave of regional agreements has led many analysts to examine the manifestation of 'New Regionalism' in the area and investigate the factors that have encouraged or inhibited regional trade integration.

Interest in this debate moved from studies that analysed earlier Arab trade initiatives in the 1950s and 1960s. Besides the contradictions between the rhetoric of Pan Arabism and the efforts of the new post-colonial governments to construct a national identity, the emphasis of those 
studies was mostly on macroeconomic issues and on the structural limitations of the Arab Mediterranean economies (Musrey, 1968; Aliboni, 1979; Owen and Pamuk, 1998). It was frequently mentioned that the relationship between the low level of development and overlapping intra-industry specialization did not allow these countries to gain much from trade integration.

Although such arguments have not entirely disappeared (Péridy, 2005; Jarreau, 2011; Ghoneim, 2013), the political economy of 'New Regionalism' was influenced by the rise of neoliberalism. This was matched by a changing intellectual attitude towards regional trade, which offered a new interpretation of the challenges for regional cooperation.

At first glance, the complementarity between 'New Regionalism' and neoliberalism looks like a paradox. There is nothing that suggests that regional trade integration is a necessary component for the success of neoliberalism. Actually, there is a significant debate among neoliberal economists about the usefulness of regional arrangements to global free trade. Yet, for scholars of 'New Regionalism' regional economic agreements offered the chance to developing countries to adopt a step-by-step approach to further liberalization and to overcome gradually the adjustment costs from the openness of their markets (Bowles, 2000).

This new view of political economy asked for the rehabilitation of the multinational corporation and market-friendly policies, which would allow export growth based on Foreign Direct Investments (FDIs). The result of this approach was that the structurally inherent aspects of the MENA economies were downplayed. Instead, the relevant literature highlighted the potential for growth from intraregional trade. In the case of the MENA, both ex-ante (Al-Atrash and Yousef, 2000; Nugent and Yousef, 2005; Péridy, 2005) and ex-post studies (Abedini and Péridy, 2008; De Wulf and Maliszewska, 2010; Khodeir, 2017) underlined the future welfare effects from more dynamic trade integration.

Market-obstructing problems were still present, but these were linked to two favourite topics of neoliberalism: (a) individual autonomy and responsibility, which was manifested as the unwillingness of politicians to engage meaningfully in regional enterprises and (b) the problematic state institutions in the MENA. In the first category, the various criticisms to the political elites of these countries echoed the individual (ir)responsibility of local policymakers, who protected key actors or sectors of domestic economies (usually for clientelistic reasons) through high tariff and non-tariff barriers. Such resistance against external liberalization discouraged intraregional cooperation among the Arab Mediterranean countries. Moreover, restrictions in labour movement and capital flows prohibited investments and the rationalization of production.

The second major category focuses on the capacity of the state mechanisms to implement the relevant agreements. In this area, there is a broad consensus among scholars (and policymakers) that the Arab Mediterranean countries have to improve significantly the performance of their state apparatus in order to fulfil their obligations. In 2004, and before the AA became operational, El Din and Ghoneim offered an early warning signal to the Egyptian authorities on the urgent need to build up the state capacity in order to 'reconcile the negative effects of rules of origin' (Kheir-El-Din and Ghoneim, 2004, 43). These effects are related to the counterproductive risks of participating in different trade agreements - what Bhagwati called a 'spaghetti bowl' phenomenon (Bhagwati, 1995). Back in 2004, the only reason why the effects of this phenomenon were not obvious was that most of the signed agreements by the Egyptian state were not yet materialized (Kheir-El-Din and Ghoneim, 2004). In the same vein, Achy and Sekkat (2005) argued that the Moroccan strategy of 'spaghetti regionalism' might reduce the chances of the country to diversify its trade (Achy and Sekkat, 2005).

Besides these issues, another important problem that the Arab Mediterranean countries must resolve is related to the harmonization of their regulatory frameworks. Regulatory convergence is perceived as key for increasing FDIs (from the other members of the Arab regional organizations). In this debate, the supportive role of external actors is considered as an essential component of success. External support takes two forms. First, external actors can provide a template for further integration. Despite the challenges of European integration, the success of the EU and the 
likelihood of the MENA countries to replicate the European experience has been an attractive topic in the relevant literature (Hoekman and Messerlin, 2002; Galal and Hoekman, 2003). When it comes to improvements of intraregional trade, two (technocratic) issues stand out. First, the expertise of EU officials is considered as a necessary input for transferring best practices and examples for the harmonization of the relevant regulations. Second, external actors (especially the EU) can stimulate regional integration by providing financial support to the MENA countries.

These elements can be found in the few studies that tried to analyse the AA. Even if most works are programmatic, as they were conducted at the early stages of the agreement, they clearly mentioned the trade potential for the members of the AA (Péridy, 2005; Boussetta, 2008). Although later studies generally acknowledged that the AA was not successful, their criticism is still rooted in neoliberal ideas and in the mainstream formalized understanding of the regional political economy.

Through these lenses, the small amount of literature on the AA suggests that the four member states should proceed more decisively to monetary reforms for achieving price stability and encouraging FDIs and to remove the various tangible and intangible barriers to trade (Abdmoulah, 2011; Dahem et al., 2014; Fardoust, 2016). The findings of reports that have been conducted for the EU member states that fund the ATU suggest that among the most important weaknesses of the AA is that policymakers have not proceeded with the necessary dynamism for the harmonization of technical regulations and voluntary standards. In addition, the systems and structures for enforcing mandatory requirements are different in each member of the AA and the weak national administrative infrastructure cannot readily process the related legal documents (Dastgeer et al., 2017). In the same vein, reports for the World Bank argue that intraregional trade could be increased if the governments of the member states became more committed to the AA. This commitment could be materialized through the expansion of the agreement to other sectors (e.g. services) and if policymakers agreed to harmonize faster the regulatory frameworks of their countries as well as allowing labour mobility (Freund and Portugal-Perez, 2012). Such decisions would not only permit the four economies to experience a much stronger growth, but they would also lay the foundation for long-term political cooperation that is much needed in the region (Oumazzane, 2018).

The neoliberal framework of the relevant bibliography offered to analysts a useful toolbox for highlighting a certain set of market distorting problems. Yet, by subsuming the short outcomes of the agreement under the categories of personal responsibilities and (bad) state institutions, the aforementioned works neglected a crucial issue: that the rulers of these countries proceeded to an agreement that relied on a well-organized basis (the EU rules of origin). Before the AA entered into force, only $8.7 \%$ of the Moroccan, Tunisian, and Jordanian exports to Egypt were duty free. In 2007, Egypt liberalized all the remaining tariff lines for all the other parties of the agreement (except those that were prohibited by the Economic and Social Council of the Arab League for security, religious, health, and environmental reasons). In the same vein, by 2007 Jordan eliminated tariffs for all imports from the other three parties (less than 1\% of Egyptian imports to the country remain dutiable). Morocco eliminated tariffs for more than $96 \%$ of imports from the other parties, while the Tunisian authorities eliminated tariffs for almost $95 \%$ of imports from the other participant countries. Before 2007, 95\% of the Jordanian, $98 \%$ of the Egyptian, and $99 \%$ of the Moroccan exports were subject to duties before they entered the Tunisian market (WTO, 2018).

Yet, the divergence between the application of international standards and incentives to tackle structural problems increased the threat of isomorphic mimicry and the likelihood of the AA to fail, even if the Arab Mediterranean countries agreed to trade within a fully liberal setting (which has proven its value elsewhere). This mimetic tendency of the local political actors is addressed in the next section. 


\section{The AA as a Mimetic System of the EU Rules of Origin}

Isomorphic mimicry refers to 'the process by which one organism mimics another to gain an evolutionary advantage' (Krause, 2013, 1). As an analytical framework in social sciences, isomorphic mimicry first appeared in organizational sociology in the early 1980s, explaining the structural similarities of organizations.

The work of DiMaggio and Powell (1983) paved the way for further research in this field. Deviating from (neo)Weberian narratives, which claimed that rationality and market competition are the main drivers of extensive bureaucratization of public and private organizations, their argument is based on the premise that the homogeneity of contemporary organizations is not driven by competition or the rules of efficiency, but by the quest for political power and institutional legitimacy. The two authors identified three isomorphic processes: coercive, normative, and mimicry. Contrary to the first two processes, which occur due to pressures from other organizations or the expansion of professional norms, mimicry appears in times of uncertainty, leading organizations and firms to structural uniformity (DiMaggio and Powell, 1983). Several organizational and field-level parameters shape mimetic systems. These include the available number of (successful) organizational models, the dependency of organizations on other firms, and the degree of uncertainty.

Much later, the concept appeared in studies of international development through the work of Andrews (2009) and Pritchett et al. (2010). The adaptation of the term suggested that the tendency of developing countries to copy institutions and policies of developed states should not be seen as a signal by the local political elites to the international community of their efforts to improve state performance, but as a method for gaining external support. The two authors put a negative sign to this endeavour. They argued that isomorphic mimicry sustains policies that do not fit in to the domestic environment of developing countries and leads to capability traps. The most important counterproductive result is 'premature load bearing': a process which overloads countries with limited resources and weak state mechanisms with unnecessary tasks that undermine performance and maintain failure.

What are the incentives for policymakers to engage in a process of isomorphic mimicry? On one side of the spectrum, for domestic actors isomorphic mimicry increases their international legitimacy. The relevant literature offers many case studies, which illustrate this tactic. Often policymakers proceed to the adoption of structural reforms, anti-corruption measures, individual aid projects, programmes, and standards which have proven their value elsewhere. Through this process, local political elites show compliance with certain norms and policy recommendations although the adopted measures do not lead to significant changes (Andrews, 2009; Pritchett et al., 2010, 2013). On the other side of the spectrum, by sustaining mimetic systems external actors uphold the values and legitimacy of their organization.

The work of Andrews (2009) and especially of Pritchett et al. (2010) received a lot of attention, not only by the scholars of international development, but also by analysts of regional integration. Through the prism of isomorphic mimicry, several scholars attempted to explain the formation of regional organizations, such as ASEAN and ECOWAS, and to identify failures of implementation (Jetschke, 2009; Piccolino, 2016). Yet, not all of them agreed with their conclusions. For some analysts, isomorphic mimicry can lead to positive results. These people claim that organizations or countries that face new challenges are often looking towards other settings or best practices in order to deal with uncertainty. In many cases, best practices borrowed from abroad were mixed with local knowledge and embedded in the local context leading to successful reforms (Dussauge-Laguna, 2012; Krause, 2013). In other cases, pressures for mimicry helped policy entrepreneurs to counter resistance from domestic elites, especially for promoting value-based policies, such as anti-corruption measures (Schnell, 2015).

Although the AA appears as a genuine South-South trade integration initiative, it has all the characteristics of a mimetic system. This system does not copy the organizational design of other regional initiatives, but the standards that inform it. 
The origins of this mimetic process can be found in the failing Arab Mediterranean regional integration initiatives of the 1980s and 1990s and the structural adjustment programmes that the four members of the AA initiated during the same period. Being forced to reduce custom tariffs, the four countries had signed bilateral free trade agreements with each other by the end of the 1990 s and agreed 'to accelerate the relatively slow-moving ten-year Pan-Arab trade liberalization programme' (Wippel, 2005, 8).

A key moment in this process was the Fourth Euro-Mediterranean Conference in Marseilles in November 2000. Reflecting the initial enthusiasm of the Barcelona Process, the participants of the Euro-Mediterranean Conference acknowledged that

the south-south regional integration process has only just begun and needs to be enhanced .... In order to provide fresh impetus to regional cooperation, the Ministers recommended strengthening the subregional aspect of the Process by encouraging the voluntary introduction of south-south development and economic integration initiatives. (Fourth EuroMediterranean Conference of Foreign Ministers 2000, 16)

In addition to their support to the subregional aspect of the Barcelona Process, the Foreign Ministers of the Euro-Mediterranean Conference welcomed the discussions between Morocco, Tunisia, Egypt, and Jordan

to establish closer links by creating a free-trade area amongst themselves, and emphasised the need for suitable back-up from the European Union to that end. (Fourth EuroMediterranean Conference of Foreign Ministers 2000, 3) [Emphasis added]

A few months later, the foreign ministers of the four countries met in Rabat to discuss further the possibility of closer cooperation. The agreement of the four countries in Rabat, and a few weeks later in Agadir, for proceeding to the establishment of a free trade area laid the foundation for a series of technical discussions about the details of the AA. These took place in Cairo in July 2001, in Amman in December 2001, in Tunis in March 2002, and in Rabat in October 2002 (Hamoudeh, 2002; Wippel, 2005).

The discussions and results of these expert meetings reveal DiMaggio's and Powell's parameters that shape mimetic systems: availability of organizational models, dependency, and uncertainty. As stated above, regarding the first parameter, the AA as a mimetic system does not copy the organizational structures of the EU institutions. The legal text of the agreement reveals the intergovernmental nature of the AA. According to it, the Foreign Ministers of the four countries are responsible for examining periodically the agreement in order to ensure that it is applied correctly. The ATU acts as a small secretariat offering advice and technical support on all matters concerning the implementation of the AA. Its function is not comparable with the supranational character and the decision-making capacity of the European Commission.

In this case, mimicry is found in the set of formal rules that inform the AA. Since the first expert meeting in Cairo, it became obvious to policymakers that they had available to them two sets of organizational principles upon which they could build the AA. The four countries had to choose between the European rules of origin or the Arab rules of origin under the Pan-Arab Free Trade Agreement.

In the second meeting in Amman, senior officials of the four countries decided to utilize the rules of origin they had agreed on with the EU in their bilateral Association Agreements. This decision was shaped by the second parameter in DiMaggio's and Powell's framework: the dependency of the AA countries on EU trade. Policymakers of the four countries decided unanimously that such a move would help them to achieve two aims. First, the members of the AA would enhance their economic and industrial integration and second they would be able to maintain (and improve) their export capabilities in the more lucrative EU market. In 2002, a 
significant percentage of exports of manufactured goods for the four Arab Mediterranean countries were towards the EU market. According to the European Commission, their exports ranged from $25 \%$ of total exports of manufactured goods and equipment for Egypt up to $70 \%$ for Tunisia (European Commission, 2018d). In order to reduce uncertainty, it was decided (in the next meeting in Tunis) that the liberalization of the market for industrial products should proceed gradually. This was to start in 2003 with the reduction of custom duties by $65 \%$. The four countries agreed to fully eliminate tariffs by 2006.

Between 2003 and 2004, the process was marked by several delays. These were related mostly to ceremonial and administrative disagreements between the four members (Wippel, 2005). The first one was about the location of the secretariat for managing the AA. The offer of the Jordanian delegation to host the secretariat of the AA was initially rejected by the Egyptian authorities. After pressures from the other three members, Egypt accepted that the location of the ATU should be in Amman. The second reason for the delay was the insistence of the Moroccan authorities to host the ceremony for the conclusion of the agreement. For this demand, a convenient solution was found. The AA was finalized in Amman in January 2003 and it was finally signed by the ministers of foreign affairs in Rabat in February 2004.

This section illustrated how the AA developed as a mimetic strategy of policymakers of the four Arab Mediterranean countries to copy the European rules of origin. Although the review of the literature above suggests that mimicry can produce positive or negative results, in the case of AA it has generated a set of important capability traps that facilitate failure. These are discussed in the next paragraphs.

\section{The Capability Traps of the AA}

A behavioural trait of the agents of mimetic strategies is that they find their initiatives successful although these are dysfunctional. In the case of the AA, its stakeholders advocate the success of the agreement despite the fact that recent reports have illustrated its poor performance (Economic and Social Commission for Western Asia, 2015; Dastgeer et al., 2017). On many occasions, such as joint meetings and press releases, policymakers from the four members of the AA suggest to other countries of the MENA to join their sub-regional trade integration initiative. Recently the executive director of the ATU, Fakhri Hazaimeh, called the four member states to further expand the scope of the agreement and to proceed to further customs cooperation (The Jordan Times, 2017).

In the same vein, the EU has encouraged this mimetic strategy since its first steps. The EU projects supported the efforts of the four Arab Mediterranean administrations to set up the ATU, to identify sectors for trade integration, and to train officials on the European rules of origin (European Commission, 2017). The Head of the EU delegation in Jordan in a joint meeting with members of the ATU mentioned that the EU funds the AA with $€ 12 \mathrm{~m}$ (The Jordan Times, 2014). In several other cases, EU policymakers have mentioned the assistance that the EU offers to the ATU (Mandelson, 2008; EU-Jordan Association Council, 2014). In line with the calls of its members, the EU also urged the other Arab Mediterranean countries to join the AA, as it is open to countries that have signed a bilateral Association Agreement with the EU (Agadir Agreement, 2004; The Jordan Times, 2014).

Such statements illustrate that isomorphic mimicry has become a sustainable strategy. As stated in the previous section, policymakers sustain and reproduce mimicry for legitimacy reasons. In the case of the AA, the members of the four countries gain recognition from the EU for adopting its notions of trade. El Aid Mahsoussi, the Executive President of the ATU, clearly stated that through the AA, the ATU and the members of the AA sought greater compliance with the EU regulations and rules of trade (The Jordan Times, 2014). The EU rewards the organization of the agreement (in this case the ATU) for adopting EU practices, despite the controversial performance of the AA for promoting trade integration. 
Some examples shed light on the contradiction between the dysfunctional character of the AA and the support it receives from the EU. Assistance to the AA is considered as a key action in the European Neighbourhood Policy Action Plans of the four countries (European Commission, 2004a,b, 2005, 2006), while a short report by EuropeAid revealed that the EU funds covered $60 \%$ of the salaries and start-up costs of the ATU in the first three years (EuropeAid, n.d.). The mid-term review of the ATU that was conducted for the Swedish Development Agency showed that this percentage increased to $92 \%$ in 2017 . The EU almost exclusively sustains the secretariat of the AA despite the fact that

the mid-term review finds that the countries currently seem to have little appetite to promote regional trade and that demand for a harmonisation process remains to be demonstrated (Dastgeer et al., 2017, 6)

Even if the dialogue between the four members of the AA has increased, the lack of appetite for further integration between policymakers of the Arab Mediterranean countries becomes obvious when one looks at the frequency of meetings between the Ministers of Trade. According to Article 24 of the AA, the four ministers should meet at least once per year ('Agadir Agreement', 2004). Instead, since 2010 they have met only twice.

The effects of insincere mimicry are visible throughout the entire agreement. According to the same report, the AA suffers from poor performance of the mechanisms of the member states, as well as from the lack of clear coordination structures and clarity about the composition of its stakeholders (Dastgeer et al., 2017). The central administration of the four countries has failed to engage the private sector in any meaningful way. As a result, the main actors for identifying the most important technical barriers to trade do not contribute much to the discussions about the future of the agreement.

These problems inform the first capability trap: premature load bearing. Although the AA was signed in 2004, it was ratified in June 2006 and its implementation started at the end of March 2007. After signing the agreement, a key challenge for the four members was to establish National Focal Points (NFPs) that would administer the AA and its position towards World Trade Organization rules, EU legislation, and other agreements. More specifically, the implementation of the agreement was delayed as the Moroccan authorities did not have the capacity to adjust the national regulations in order to comply both with the agricultural provisions of the AA and with the different rules of origin of the Free Trade Agreement that the country had signed earlier with the US (De VIlle and Reynaert, 2010; Bilaterals.org, 2017).

Even if the Moroccan NFP has managed to overcome this problem, the four members 'do not seem to have the national administrative infrastructure in place to administer the Agadir Agreement and other related legal documents' (SWEDAC, 2015, 15). In this case, premature load bearing is demonstrated not only in the slow coordination of the different international obligations of the AA members, but also in the slow harmonization process for the goods sectors that fall under the AA. The fact that the countries have different harmonization structures adds a heavy burden on their central administrations.

Ten years after the AA entered into force the central administrations have managed to provide tables of correspondence for one product (low voltage cables) and one sector (garments). At this point, it must be noted that the tables of correspondence mark only the beginning of the harmonization process, as they are working documents, which identify the differences between the countries (in areas such as legislation, standards and accreditation procedures). According to the mid-term review of the AA, the four countries are still far from producing concrete results and the current small progress is the result of considerable expenses that do not justify the time and resources of the EU (Dastgeer et al., 2017, 6). In this process, the ATU is not capable of offering any help, as it does not have the specialized personnel, nor its own resources. Moreover, the AA suffers from the absence of a documented system that would 
allow the four countries to continue the harmonization of their regulations without external support.

This lack of progress led the authors of the mid-term review to suggest to the Swedish Development Agency 'to come up with a realistic, owned and achievable exit strategy' (Dastgeer et al., 2017, 7). Yet, as stated above, the disappointing results of the AA did not change the course of action for the EU, which continues to fund the agreement.

This phenomenon occurs as the EU disproportionally benefits from the AA, despite its organizational problems. This situation generates the second capability trap of the AA: the reproduction of structural problems of the Arab Mediterranean economies. A report that was prepared for the European Parliament highlights the limited impact of the AA on generating trade between local companies of the Arab Mediterranean countries. Instead it

seems to have had the effect of diverting trade flows to the benefit of countries not party to the agreement. The latter have been able to insist on taking advantage of the accumulation of pan-Euro-Mediterranean rules of origin that are part of the agreement, which itself benefited from EU assistance. Indeed, this regional accumulation of rules of origin resulted in an administrative complexity that managed to hamper trade. (Jolly, 2014, 9) [Emphasis added].

The findings of this report are corroborated by other analyses, which reveal the contradictory results of the AA for local producers in the Arab Mediterranean countries (Abdmoulah, 2011; Jolly, 2014; Dastgeer et al., 2017), even if these problems are downplayed by the literature on 'New Regionalism'. The question that emerges here is how the rules of origin contribute to the reproduction of structural problems.

As stated in the introduction, the Pan-European rules of origin allow diagonal cumulation. This clause in the AA encourages the use of materials and processing between the members of the AA and the EU. The problem in this case is that the rules of origin are very restrictive and they become more expensive for countries with problematic custom mechanisms (Brenton and Manchin, 2003). This issue has been identified by the Jordanian authorities, which in 2016 asked the EU to relax the rules of origin in order to help its producers to benefit from more access to the EU market. The EU agreed to:

A temporary relaxation of applicable rules of origin would allow for certain goods produced in Jordan to be subject to less stringent rules of origin for the purpose of determining preferential treatment on import into the Union than would otherwise apply. (EU-Jordan Association Committee, 2016, 6).

Yet, the temporary relaxation of the rules of origin only applied to the bilateral Association Agreement between the EU and Jordan and did not include the other members of the AA. The main problem here is that through such practices the EU strengthens trade between itself (as a hub) and the other Arab Mediterranean countries (as its spokes), rather than between the AA countries.

The hub-spokes effect is encouraged not only by the EU's differential treatment of the members of the AA, but also by the AA itself. At first glance, this seems like a paradox as the aim of the AA is to create more trade between the Arab Mediterranean countries and to re-orientate trade away from the EU and towards the members of the agreement. Yet, trade creation and trade reorientation is becoming a more challenging task as the structure of the economies of the AA members is similar (Boussetta, 2008). This is an issue that is masked by the rhetoric of 'New Regionalism', which highlights the potential of growth from trade integration. However, the exports of these countries are highly concentrated in primary products, low technology goods, and in sectors with high use of domestic intermediate inputs. In this case, diagonal cumulation has limited effects, as local producers either do not choose to source intermediates 
from the other AA economies or when they do so, they do it only for the production of low-value goods.

Gasiorek et al. (2008) offer some very interesting insights into the difficulties that local producers face in the Egyptian textiles sector. They argue that in this sector Egyptian producers easily receive certificates for the rules of origin, as they use mainly local resources. Yet, when they decide to move up in the value chain, then the situation changes and the rules of origin add more costs to their international operations (Gasiorek et al., 2008). The Arab Development Outlook that was prepared by the Economic and Social Commission for Western Asia for the United Nations (UN) corroborate their findings (Economic and Social Commission for Western Asia, 2015). It claims that the AA has failed to remedy the asymmetric effect of the rules of origin. Local producers are involved in outward processing schemes, which allow EU goods to be processed abroad and when the goods come back into the EU, duty has to be paid only on the value added abroad. As a result, the Arab Mediterranean countries provide low value-added output and the EU is specialized in higher added value activities.

The UN report clearly states that the preferential rules of origin 'have been tailored to the industrial landscape of developed partners and are applied, with little margin for derogations, across the board' (Economic and Social Commission for Western Asia, 2015, 141). Brenton and Manchin (2003) explain what this form of mimicry of the EU set of rules entails for local producers. It ensures that producers 'are locked in to using high cost inputs from the EU' (Brenton and Manchin, 2003, 767), if they wish to benefit from the reduction of tariff barriers.

Trade statistics corroborate the aforementioned views. At this point, it should be mentioned that there are significant disparities between gravity analyses casting some degree of doubt on the methodology and tools they use for assessing intraregional trade (for a review in the literature, see Jarreau, 2011; Economic and Social Commission for Western Asia, 2015). However, despite their differences, official reports and econometric studies show that since the AA became operational, the trade volumes between the four members of the AA have been very low and only Egypt enjoys a trade surplus against the other three members (WTO, 2018). The share of imports and exports of industrial goods between Jordan, Morocco, and Tunisia is minimal and ranges between $2 \%$ and $7 \%$ of their total trade (since the agreement entered into force). At this point, it is important to mention that external shocks, such as the Arab revolts, hindered trade temporarily, but they are not the cause of the low trade flow pattern. According to Freund and Portugal-Perez (2012), the AA does not produce significantly different results when compared to the regional trade agreements. Earlier studies on sub-regional integration underlined the very limited trade among the members of the AA and their heavy dependence on the EU (Escribano and Jordán, 1999).

In fact, the EU has improved its position in the trade flows of the four countries over the last 13 years (and despite the hiccup of the Arab revolts) (for an overview see Alcidi et al., 2017; Dadush and Myachenkova, 2018). Latest reports reveal EU dominance in the trade relations of the members of the AA. In 2017, the EU absorbed $78.5 \%$ of Tunisia's exports while $54.3 \%$ of Tunisia's imports came from the EU. More than $65 \%$ of the goods that were exchanged were industrial products that fell under a free trade agreement between the AA members (European Commission, 2018e). In the same year, 65\% of the goods Morocco traded with the EU also fell under the AA (European Commission, 2018c), while EU-Egypt trade more than doubled from $€ 11.8$ bn in 2004 to $€ 27.9 b n$ in 2017 (European Commission, 2018a). Almost 30\% of EU-Egypt trade includes products that fall under the AA. Although the EU is Jordan's largest trading partner, it accounted for just under $18 \%$ of its trade in 2017 . Even if trade between the EU and Jordan is small, more than $60 \%$ covers products that fall under the AA (European Commission, 2018b).

Measures that could mitigate the costs that this mimetic strategy imposes on local producers are not included in the AA. Based on the analysis above, a short list of recommendations includes the following suggestions. 
As it did in the case of Jordan, the EU should relax the rules of origin (at least temporarily) for all the members of the AA (for intraregional trade) in order to encourage their cooperation. This transition period should have clear performance benchmarks for increasing trade among the Arab Mediterranean partners. Besides funding the apparatus of the AA, what is needed for such an ambitious plan to succeed is a financial assistance programme that compensates the four members from losses of revenues from the elimination of custom controls.

To mitigate the structural limitations of the local economies, the AA should also include targeted financial incentives for local producers to seek opportunities in the regional market. For this to happen, the stakeholders of the AA need to consider the level of industrial sophistication in the region and how local industries source intermediate inputs. Emphasis on mimicking the EU rules of origin across the board diverts attention from these areas and from the creation of an institutional framework, which would encourage the implementation of cross-national projects in sectors, where these countries enjoy comparative advantages (e.g. energy) or of strategic priority (e.g. water, knowledge economy).

\section{Conclusion}

This article fills a gap in the bibliography of regional cooperation between the Arab Mediterranean countries by analysing the AA. It deploys the concept of isomorphic mimicry to explain the replication of the EU rules of origin and how these inform the performance of this regional trade initiative.

Contrary to the relevant bibliography, which to a large extent recycles narratives from the political economy of 'New Regionalism' and emphasizes the potential gains from the transfer of the EU rules to the AA, this study argues that this form of mimicry has produced poor results. On the one hand, it improved the legitimacy of policymakers, who 'proved' to the EU their willingness to apply good international practices (the EU rules of origin). On the other hand, this process generated mechanisms of persistent implementation failure. These are premature load bearing and the reproduction of the structural problems of the four Arab Mediterranean partners.

The problematic state institutions are mentioned in the literature of 'New Regionalism'. Yet these studies are informed by neoliberal narratives, which underline their low capacity to cultivate an open-trade environment in the developing economies. According to this literature, a remedy to this problem is external support from the EU. Differently from this approach, premature load bearing refers to the significant costs that such open-trade endeavours add to governments with poor resources. Despite signing the AA and the help from the EU, the Arab Mediterranean states have so far struggled to implement the imported standardizing devices and to align the new sets of practices with their other international obligations.

Besides the high administrative costs, the AA does not solve the structural problems of the local economies. Instead, it encourages local businesses to trade with the EU and keeps local actors locked into the production of low-added value inputs to the Euro-Mediterranean value chain. This situation inhibits trade reorientation, as the four members do not switch sources of supply away from the EU and towards the other members of the AA. In a subtle way, the AA contributes to the reproduction of the hub-spoke effect.

\section{References}

Abdmoulah, W. (2011) 'Arab Trade Integration: Evidence from Zero-Inflated Negative Binomial Model', Journal of Economic Cooperation and Development 32(2), 39-66.

Abedini, J. and N. Péridy (2008) 'The Greater Arab Free Trade Area(GAFTA): An Estimation of Its Trade Effects on JSTOR', Journal of Economic Integration 23(4), 848-872.

Achy, L. and K. Sekkat (2005) 'Overlapping Trade Agreements: Status and Challenges for Morocco', 0427, Research Report Series, Economic Research Forum, Giza. 
Agadir Agreement (2004) www.agadiragreement.org/AgadierAgrement/Agreementtext.aspx.

Agadir Technical Unit (2015) 'About Agadir - Agadir', www.agadiragreement.org/Pages/viewpage.aspx?pageID=168.

Al-Atrash, H. and T. Yousef (2000) 'Intra-Arab Trade: Is It Too Little?', WP/00/10. IMF Working Paper, International Monetary Fund, Washington, DC.

Alcidi, C., M. Busse, C. Zaki, N. AbouShady, N. Alshyab, A.A. El Mekki, A. Abbassi, R. Hadhri, and H. Ayari (2017) Trade and Investment in the Mediterranean: Country and Regional Perspectives, 2. EMNES Studies (n.p). Barcelona: Euro-Mediterranean Network For Economic Studies (EMNES).

Aliboni, R. (ed.) (1979) Arab Industrialization and Economic Integration. London: Croom Helm Ltd.

Andrews, M. (2009) 'Isomorphism and the Limits to African Public Financial Management Reform', Working Paper RWP09-012, HKS Faculty Research Working Paper Series, Harvard University, Cambridge, MA.

Barbé, E. and A.H. Surrallés (2010) 'Dynamics of Convergence and Differentiation in Euro-Mediterranean Relations: Towards Flexible Region-Building or Fragmentation?', Mediterranean Politics 15(2), 129-147, doi:10.1080/13629395.2010.485032.

Bhagwati, J. (1995) 'US Trade Policy: The Infatuation with FTAs', 726, Discussion Paper Series, Columbia University, New York.

Bilaterals.org. (2017) 'Agadir Agreement', www.bilaterals.org/?-agadir-agreement-.

Boussetta, M. (2008) 'Integration Sud-Sud Et Son Impact Sur Les Pays Arabes Du Sud De La Mediterranee: Le Cas Des Pays De La Declaraion D’Agadir', Working Paper 447, Economic Research Forum, Giza

Bowles, P. (2000) 'Regionalism and Development after(?) The Global Financial Crises', New Political Economy 5(3), 433-455.

Brenton, P. and M. Manchin (2003) 'Making EU Trade Agreements Work: The Role of Rules of Origin', The World Economy 26(5), 755-769.

Dadush, U. and Y. Myachenkova. (2018) 'Assessing the European Union's North Africa Trade Agreements', 22, Policy Contributions, Bruegel, Brussels.

Dahem, A., D. Saidane, and F.S. Guermazi (2014) 'Drivers and Forecasting Inflation for Agreement Agadir Countries', Journal of World Economic Research 3(6), 33-38.

Dastgeer, A., B. Kreitem, J. Andersson, and S. Ciarli (2017) 'Mid Term Review of the Agadir Technical Unit and the Swedish International Development Agency, Sida Funded Project "Support Quality Infrastructure in Agadir Countries”, Final Report Sida62073en, Swedish International Development Cooperation Agency, Stockholm

De Ville, F. and V. Reynaert (2010) 'The Euro-Mediterranean Free Trade Area: An Evaluation on the Eve of the (Missed) Deadline', L'Europe En Formation 2, 193-206, doi:10.3917/eufor.356.0193.

De Wulf, L. and M. Maliszewska (2010) Prospects for Future Euro-Mediterranean Trade. Warsaw: Center for Social and Economic Research.

DiMaggio, P.J. and W.W. Powell (1983) 'The Iron Cage Revisited: Institutional Isomorphism and Collective Rationality in Organizational Fields', American Sociological Review 48(2), 147-160, doi:10.2307/2095101.

Dussauge-Laguna, M.I. (2012) 'The Neglected Dimension: Bringing Time Back into Cross-National Policy Transfer Studies', Policy Studies 33(6), 567-585, doi:10.1080/01442872.2012.728900.

Economic and Social Commission for Western Asia (2015) 'Arab Development Outlook: Vision 2030', E/ESCWA/EDID/ 2015/3, United Nations, Beirut.

Escribano, G. and J.M. Jordán (1999) 'Sub-regional Integration in the MENA Region and the Euro-mediterranean Free Trade Area', Mediterranean Politics 4(2), 133-148, doi:10.1080/13629399908414690.

EU-Jordan Association Council (2014) 'Minutes of the 11th Meeting of the EU-Jordan Association Council', EU-Jordan Association Council, Brussels.

EU-Jordan Association Committee (2016) 'Decision No 1/2016 of the EU-Jordan Association Committee. 2016/1436'. https://eur-lex.europa.eu/legal-content/EN/TXT/PDF/?uri=CELEX:22016D1436\&from=EN.

EuropeAid (n.d) Economic Development Support to the Implementation of the Arab-Mediterranean Free Trade Agreement. Brussels: EuropeAid.

European Commission (2004a) 'EU/Morocco Action Plan', Brussels, http://ec.europa.eu/world/enp/pdf/action_plans/morocco_ enp_ap_final_en.pdf.

European Commission (2004b) 'EU/Tunisia Action Plan', Brussels, http://ec.europa.eu/world/enp/pdf/action_plans/tunisia_ enp_ap_final_en.pdf.

European Commission (2005) 'EU/Jordan Action Plan', Brussels, https://library.euneighbours.eu/content/eu-jordan-enpaction-plan.

European Commission (2006) 'EU/Egypt Action Plan’, Brussels, http://ec.europa.eu/world/enp/pdf/action_plans/egypt_enp_ ap_final_en.pdf.

European Commission (2017) 'Agadir Agreement-EU Support Project | EU Neighbours', www.euneighbours.eu/en/south/ stay-informed/projects/agadir-agreement-eu-support-project.

European Commission (2018a) 'Egypt-Trade-European Commission', http://ec.europa.eu/trade/policy/countries-andregions/countries/egypt/index_en.htm.

European Commission (2018b) 'Jordan-Trade-European Commission', http://ec.europa.eu/trade/policy/countries-andregions/countries/jordan/index_en.htm. 
European Commission (2018c) 'Morocco-Trade-European Commission', http://ec.europa.eu/trade/policy/countries-andregions/countries/morocco/index_en.htm.

European Commission (2018d) 'Negotiations and Agreements-Trade', http://ec.europa.eu/trade/policy/countries-andregions/negotiations-and-agreements/.

European Commission (2018e) 'Tunisia-Trade-European Commission', http://ec.europa.eu/trade/policy/countries-andregions/countries/tunisia/index_en.htm.

European Commission (n.d.) 'Taxation and Customs Union', Accessed 23 September 2018, https://ec.europa.eu/taxation_ customs/business/calculation-customs-duties/rules-origin/general-aspects-preferential-origin/common-provisions_en.

Fardoust, S. (2016) 'Economic Integration in the Middle East', 2016-5, MEI Policy Papers, The Middle East Institute, Washington, DC.

Fourth Euro-Mediterranean Conference of Foreign Ministers (2000) 'Fourth Euro-Mediterranean Conference of Foreign Ministers: Presidency's Formal Conclusions', Marseille.

Freund, C. and A. Portugal-Perez (2012) 'Assessing MENA's Trade Agreements', 55, Working Paper Series, The World Bank, Washington, DC.

Galal, A. and B. Hoekman (eds.) (2003) Arab Economic Integration. Washington, DC: Brookings Institution Press, 1-12.

Gasiorek, M., P. Augier, and C. Lai-Tong (2008) The Impact of Diagonal Cumulation of Rules of Origin in the Context of Euro-Med Integration (FEM 31-13). Marseille: FEMISE.

Ghoneim, A. (2013) 'Trade and Investment Dynamics in the Mediterranean Region: No Real Change after the Arab Spring', in S. Colombo (ed.), Regional Dynamics in the Mediterranean and Prospects for Transatlantic Cooperation, Mediterranean Paper Series, The German Marshall Fund of the United States, Washington, DC, 1-12.

Hamoudeh, M. (2002) 'The Aghadir Process', Presented at the Mediterranean Academy of Diplomatic Studies, University of Malta, May.

Hoekman, B. and P. Messerlin (2002) 'Initial Conditions and Incentives for Arab Economic Integration: Can the European Community's Success Be Emulated?', Policy Research Working Papers, The World Bank, Washington, DC, doi:10.1596/ 1813-9450-2921.

Jarreau, J. (2011) 'Economic Integration in the EuroMed: Current Status and Review of Studies', Document De Travail 07, Centre d'Études Prospectives et d'Informations Internationales, Paris.

Jetschke, A. (2009) 'Institutionalizing ASEAN: Celebrating Europe through Network Governance', Cambridge Review of International Affairs 22(3), 407-426, doi:10.1080/09557570903107688.

Jolly, C. (2014) 'Regional Integration in the Mediterranean: Impact and Limits of Community and Bilateral Policies', European Parliament Committee on Foreign Affairs, Brussels.

Kheir-El-Din, H. and A.F. Ghoneim (2004) 'The Economic and Regulatory Policy Implications of Overlapping Preferential Trade Agreements in the Arab Countries: The Case of Egypt', 0425, Research Report Series, Economic Research Forum, Giza, http://erf.org.eg/publications/the-economic-and-regulatory-policy-implications-of-overlapping-preferentialtrade-agreements-in-the-arab-countries-the-case-of-egypt/.

Khodeir, A.N. (2017) 'Intra-Trade in Arab Manufacturing Industries as a Determinant of the Technological Progress', Arab Economic and Business Journal 12(1), 1-12, doi:10.1016/j.aebj.2017.04.004.

Krause, P. (2013) 'Of Institutions and Butterflies: Is Isomorphism in Developing Countries Necessarily a Bad Thing?', Background Note, Overseas Development Institute (ODI), London.

Mandelson, P. (2008) 'Agadir and After: Prospects for a Free Trade Area of the Mediterranean', Presented at the First Agadir Investment Forum, Brussels, http://trade.ec.europa.eu/doclib/docs/2008/april/tradoc_138488.pdf.

Musrey, A.G. (1968) Inter-Arab Trade Relations, 1920-1963: A Chapter in Economic History. New York: Columbia University Press.

Nugent, J. and T. Yousef. (2005) 'Does MENA Defy Gravity? How MENA Has Performed in Its Intraregional, EU and Other Trade: Implications for EU and Intra-MENA Trade Arrangements', 2005/26, EUI Working Papers, European University Institute, Florence, http://cadmus.eui.eu//handle/1814/3248.

Oumazzane, T. (2018) 'An Assessment of the Economic and Political Impacts of the Agadir Agreement: Promoting Peace and Stability in the Middle East and North Africa', Ph.D. thesis. Nottingham Trent University, Nottingham.

Owen, R. and Ş. Pamuk (1998) A History of Middle East Economies in the Twentieth Century. London: I.B.Tauris.

Péridy, N. (2005) 'Toward a Pan-Arab Free Trade Area: Assessing Trade Potential Effects of the Agadir Agreement', The Developing Economies 43(3), 329-345, doi:10.1111/j.1746-1049.2005.tb00948.x.

Piccolino, G. (2016) 'International Diffusion and the Puzzle of African Regionalism: Insights from West Africa', Working Paper 2016/1, United Nations University, Bruges.

Pritchett, L. (2013) 'Looking Like a State: Techniques of Persistent Failure in State Capability for Implementation', The Journal of Development Studies 49(1), 1-18, doi:10.1080/00220388.2012.709614.

Pritchett, L., M. Woolcock, and M. Andrews. (2010) 'Capability Traps? The Mechanisms of Persistent Implementation Failure', Working Paper 234, Center for Global Development, Washington, DC.

Schnell, S. (2015) 'Mimicry, Persuasion, or Learning? The Case of Two Transparency and Anti-Corruption Policies in Romania', Public Administration and Development 35(4), 277-287, doi:10.1002/pad.1721. 
SWEDAC (2015) 'Annual Results for SWEDAC’s Agadir Programme Phase II', SWEDAC, Stockholm.

The Jordan Times (2014) 'Jordan, EU Urge More Arab States to Join Agadir Agreement', The Jordan Times, 8 February 2014, www.jordantimes.com/news/business/jordan-eu-urge-more-arab-states-join-agadir-agreement.

The Jordan Times (2017) 'Agadir Agreement Members Discuss Customs Cooperation', The Jordan Times, 16 November 2017, www.jordantimes.com/news/local/agadir-agreement-members-discuss-customs-cooperation.

Vasconcelos, Á. and G. Joffé (2000) 'Towards Euro-Mediterranean Regional Integration', Mediterranean Politics 5(1), 3-6, doi:10.1080/13629390008414705.

Wippel, S. (2005) 'The Agadir Agreement and Open Regionalism', 45, EuroMesco Papers, EuroMesco, Lisbon.

World Trade Organization (WTO) (2015) 'International Trade Statistics 2015', World Trade Organization, Geneva, www.wto. org/english/res_e/statis_e/its2015_e/its2015_e.pdf.

WTO (2018) 'Factual Presentation: Arab Mediterranean Free Trade Agreement (Agadir Agreement) between Egypt, Jordan, Morocco and Tunisia (Goods)', WT/COMTD/RTA/11/1, World Trade Organization, Geneva.

WTO (2019) 'World Trade Statistical Review 2019', World Trade Organization, Geneva, www.wto.org/english/res_e/statis_e/ wts2019_e/wts2019_e.pdf.

Wunderlich, D. (2010) 'Differentiation and Policy Convergence against Long Odds: Lessons from Implementing EU Migration Policy in Morocco', Mediterranean Politics 15(2), 249-272, doi:10.1080/13629395.2010.485052.

Zaafrane, H. and A. Mahjoub (2000) 'The Euro-Mediterranean Free Trade Zone: Economic Challenges and Social Impacts on the Countries of the South and East Mediterranean', Mediterranean Politics 5(1), 9-32, doi:10.1080/13629390008414706.

Cite this article: Kourtelis C (2021). The Agadir Agreement: The Capability Traps of Isomorphic Mimicry. World Trade Review 20, 306-320. https://doi.org/10.1017/S1474745620000488. 